Buddhism AND Modernity 



\section{Buddhism and Modernity}

Sources from Nineteenth-Century Japan

EDITED BY

Orion Klautau

AND

Hans Martin Krämer

Wint

University of Hawai'i Press

Honolulu 
(C) 2021 University of Hawai'i Press

All rights reserved

Printed in the United States of America

$\begin{array}{llllllllllll}26 & 25 & 24 & 23 & 22 & 21 & 6 & 5 & 4 & 3 & 2 & 1\end{array}$

\section{Library of Congress Cataloging-in-Publication Data}

Names: Klautau, Orion, editor. I Krämer, Hans Martin, editor.

Title: Buddhism and modernity : sources from nineteenth-century Japan / Orion Klautau, Hans Martin Krämer.

Description: Honolulu : University of Hawai'i Press, 2021. I Includes bibliographical references and index.

Identifiers: LCCN 2020030496 I ISBN 9780824884581 (hardcover) I ISBN 9780824888138 (epub) I ISBN 9780824888145 (kindle edition) I ISBN 9780824888121 (adobe pdf)

Subjects: LCSH: Buddhism-Japan-History-19th century-SourcesTranslations into English.

Classification: LCC BQ674 .B83 2021 I DDC 294.30952/09034-dc23

LC record available at https://lccn.loc.gov/2020030496

University of Hawai'i Press books are printed on acid-free paper and meet the guidelines for permanence and durability of the Council on Library Resources.

Cover art: Félix Régamey, Émile Guimet devant un bonze avec comme interprète Kondo à Niko, ca. 1876-1877. Paris, Musée national des arts asiatiquesGuimet (courtesy of bpk / RMN-Grand Palais / Mathieu Rabeau). In 1876, the French art collector Émile Guimet (1836-1918) and the painter Félix Régamey (1844-1907) traveled through Japan. In this painting, Régamey depicts Guimet exchanging information on religion with a Buddhist priest, most likely Hikosaka Jinkō (1833-1897), deacon of the Tendai temple Manganji, in a hotel room in Nikkō. In the center, Kondō Tokutarō (1856-1920) acts as interpreter. 